\title{
Palladium-catalyzed 2,5-diheteroarylation of 2,5-dibromothiophene derivatives
}

\author{
Fatma Belkessam ${ }^{1,2}$, Aidene Mohand ${ }^{2}$, Jean-François Soulé ${ }^{1}$, Abdelhamid Elias ${ }^{*} 1,2$ \\ and Henri Doucet ${ }^{* 1}$
}

\section{Full Research Paper}

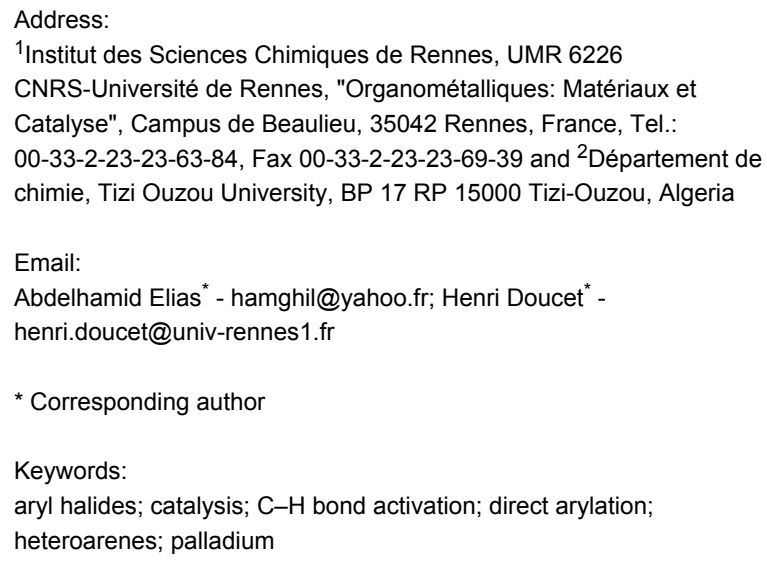

Beilstein J. Org. Chem. 2014, 10, 2912-2919. doi:10.3762/bjoc.10.309

Received: 13 October 2014

Accepted: 27 November 2014

Published: 09 December 2014

Associate Editor: C. Stephenson

(C) 2014 Belkessam et al; licensee Beilstein-Institut. License and terms: see end of document.

\begin{abstract}
Conditions allowing the one pot 2,5-diheteroarylation of 2,5-dibromothiophene derivatives in the presence of palladium catalysts are reported. Using KOAc as the base, DMA as the solvent and only $0.5-2 \mathrm{~mol} \%$ palladium catalysts, the target 2,5-diheteroarylated thiophenes were obtained in moderate to good yields and with a wide variety of heteroarenes such as thiazoles, thiophenes, furans, pyrroles, pyrazoles or isoxazoles. Moreover, sequential heteroarylation reactions allow the access to 2,5-diheteroarylated thiophenes bearing two different heteroaryl units.
\end{abstract}

\section{Introduction}

2,2':5',2"-Terthiophene (or 2,5-di(2-thienyl)thiophene) (Figure 1) and many of its derivatives are important structures due to their biological and/or physical properties. For example, $2,2^{\prime}: 5^{\prime}, 2^{\prime \prime}$-terthiophene itself is a pigment of Tagetes minuta. Some 2,2':5',2"-terthiophene derivatives such as 5,5"-dichloro$\alpha$-terthiophene also occur naturally [1]. Moreover, terthiophenes are widely used as building blocks for the synthesis of semiconductors [2]. Due to these multiple uses, the discovery of a simpler access to terthiophene derivatives would be very useful.

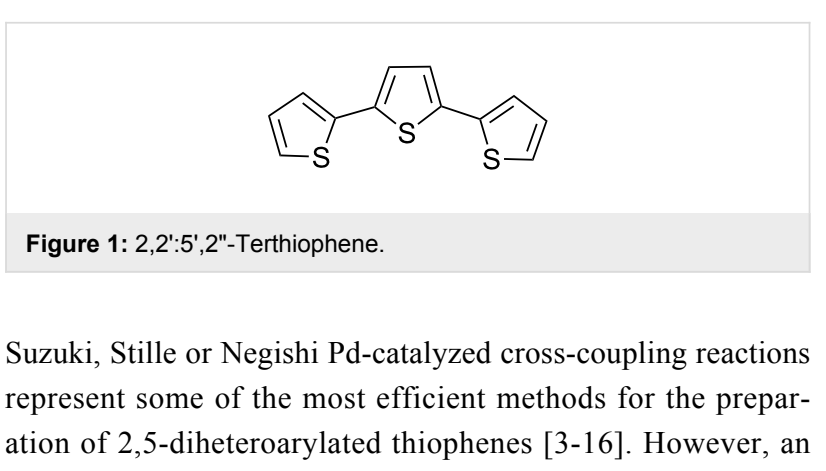


organometallic derivative must be prepared to perform such reactions. In 1990, Ohta and co-workers reported the Pd-catalyzed direct arylation of heteroaromatics using aryl halides as coupling partners via a $\mathrm{C}-\mathrm{H}$ bond activation $[17,18]$. Since then Pd-catalyzed direct arylation of heteroaryls, especially with aryl halides as coupling partners, has been shown to be a very powerful method for an easier and greener access to a very broad range of arylated heterocycles [19-32]. This method is more attractive than other Pd-catalyzed cross-coupling reactions as it avoids the preparation of an organometallic derivative and also as the major byproducts of the reaction are not metallic salts but a base associated to HX.

The metal-catalyzed direct arylation of a wide variety of heteroarenes using aryl halides as coupling partners has been reported in recent years [19-36]. However, to our knowledge, only a few examples of Pd-catalyzed direct arylations at both $\mathrm{C} 2$ and $\mathrm{C} 5$ carbons of 2,5-dihalothiophene derivatives have been described. In 2006, Borgese et al. reported the Pd-catalyzed coupling of 2,5-dibromothiophene with 3-methoxythiophene to afford the corresponding terthiophene in $29 \%$ yield [37]. From 2,5-diiodothiophene and benzoxazole, using $5 \mathrm{~mol} \% \mathrm{Pd}(\mathrm{phen})_{2}\left(\mathrm{PF}_{6}\right)_{2}$ catalyst, the 2,5-diheteroarylated thiophene was obtained in $89 \%$ yield by Murai et al. [38]. A fluorescent $\pi$-conjugate thiophene derivative bearing spiro[fluorene-9,4'-[4H]indeno[1,2-b]furan] substituents at C2 and $\mathrm{C} 5$ has been prepared in $46 \%$ yield by this reaction using $\mathrm{Pd}(\mathrm{OAc})_{2}(5 \mathrm{~mol} \%)$ associated to $\mathrm{PPh}_{3}(10 \mathrm{~mol} \%)$ as catalytic system [39]. A pyrrole derivative was coupled with 2,5-dibromothiophene in the presence of $\mathrm{Pd}(\mathrm{OAc})_{2}(5 \mathrm{~mol} \%)$ and $\mathrm{PCy}_{3}$ $(10 \mathrm{~mol} \%$ ) catalyst to afford the 2,5-di(pyrrolyl)thiophene in $59 \%$ yield [40]. Finally, an indolizine was also successfully coupled with 2,5-dibromothiophene in $47 \%$ yield in the presence of $\mathrm{Pd}(\mathrm{OAc})_{2}$ as catalyst [41]. To our knowledge, so far sequential Pd-catalyzed direct couplings using 2,5-dihalothiophene derivatives have not been described. Therefore, the discovery of effective general conditions, for the direct coupling of heteroarenes at both $\mathrm{C} 2$ and $\mathrm{C} 5$ positions of 2,5-dihalothiophene derivatives, would constitute a considerable advantage allowing a simpler access to terthiophene derivatives.

Here, we wish to report (i) that only $0.5-2 \mathrm{~mol} \%$ of air-stable palladium catalysts associated to KOAc promote the direct access to 2,5-diheteroarylated thiophenes in one pot, (ii) on the reaction scope using a large set of heteroarenes, and (iii) conditions allowing the sequential diheteroarylation of 2,5-dibromothiophene.

\section{Results and Discussion}

Based on our previous results, DMA was initially chosen as the solvent and KOAc as the base for this study $[42,43]$. The reactions were conducted at $140{ }^{\circ} \mathrm{C}$ under inert conditions using $\mathrm{PdCl}\left(\mathrm{C}_{3} \mathrm{H}_{5}\right)(\mathrm{dppb})$ or $\mathrm{Pd}(\mathrm{OAc})_{2}$ catalysts. Using only $0.5 \mathrm{~mol} \% \mathrm{Pd}(\mathrm{OAc})_{2}$, the reaction of 1 equiv of 2,5-dibromothiophene with 2 equiv 2-ethyl-4-methylthiazole as coupling partners affords the mono- and diarylation products $\mathbf{1 a}$ and $\mathbf{1 b}$ in a 2:98 ratio and the desired product $\mathbf{1 b}$ was isolated in $79 \%$ yield (Scheme 1, Table 1, entry 1). The use of 3 equiv of 2-ethyl-4methylthiazole afforded $\mathbf{1 b}$ in similar yield (Table 1, entry 2). Then, we examined the influence of the amount of catalyst and other parameters on the reaction. The use of 1 or $2 \mathrm{~mol} \%$ $\operatorname{PdCl}\left(\mathrm{C}_{3} \mathrm{H}_{5}\right)(\mathrm{dppb})$ catalyst, which had been previously found to be very effective to promote the direct arylation of several hereroaromatics [42-44], also afforded $\mathbf{1 b}$ in high yields (Table 1, entries 3-5). Even at $100{ }^{\circ} \mathrm{C}$, the desired product $\mathbf{1 b}$ was obtained in $78 \%$ yield (Table 1, entry 6 ). When CsOAc was employed as the base instead of KOAc, in the presence of $2 \mathrm{~mol} \% \mathrm{PdCl}\left(\mathrm{C}_{3} \mathrm{H}_{5}\right)(\mathrm{dppb})$ catalyst, $\mathbf{1 b}$ was isolated in $80 \%$ yield, whereas $\mathrm{NaOAc}$ led to target product $\mathbf{1 b}$ in only $68 \%$ yield and $\mathrm{Cs}_{2} \mathrm{CO}_{3}$ was ineffective (Table 1, entries 7-9). It should be noted that in the presence of an excess of 2,5-dibromothiophene (4 equiv) with 1 equiv of 2-ethyl-4-methylthiazole the products $\mathbf{1 a}$ and $\mathbf{1 b}$ were produced in a 72:28 ratio and 1a was isolated in $52 \%$ yield, without cleavage of the second $\mathrm{C}-\mathrm{Br}$ bond on the thiophene ring allowing sequential arylations (Table 1, entry 10).

Then, with the most effective reaction conditions in hand for diheteroarylation (DMA, KOAc, $\mathrm{Pd}(\mathrm{OAc})_{2}$ or $\mathrm{PdCl}\left(\mathrm{C}_{3} \mathrm{H}_{5}\right)(\mathrm{dppb}), 100$ or $\left.140{ }^{\circ} \mathrm{C}, 20 \mathrm{~h}\right)$, we explored the scope of this reaction using a variety of heteroarenes as the coupling partner (Scheme 2).

First, we investigated the reaction of 2,5-dibromothiophene with 4-methylthiazole (Scheme 2 ). The reaction proceeded very smoothly to afford the product 2 in $82 \%$ yield. It should be noted that no arylation at $\mathrm{C} 2$ of this thiazole derivative was observed. Then, a set of thiophene derivatives was employed.

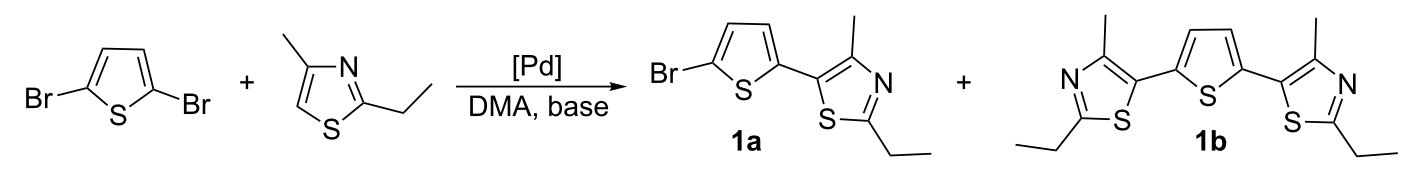

Scheme 1: Palladium-catalyzed direct arylation using 2,5-dibromothiophene and 2-ethyl-4-methylthiazole as coupling partners. 
Table 1: Influence of the reaction conditions for palladium-catalyzed direct arylation using 2,5-dibromothiophene and 2-ethyl-4-methylthiazole as coupling partners (Scheme 1). ${ }^{a}$

\begin{tabular}{|c|c|c|c|c|c|c|}
\hline Entry & Catalyst (mol \%) & Base & $\begin{array}{l}\text { 2-Ethyl-4-methylthiazole } \\
\text { (equiv) }\end{array}$ & Temperature $\left({ }^{\circ} \mathrm{C}\right)$ & Ratio 1a:1b & $\begin{array}{l}\text { Yield in } \mathbf{1 b} \\
(\%)\end{array}$ \\
\hline 1 & $\mathrm{Pd}(\mathrm{OAc})_{2}(0.5)$ & KOAC & 2 & 140 & $2: 98$ & 79 \\
\hline 2 & $\mathrm{Pd}(\mathrm{OAc})_{2}(0.5)$ & KOAC & 3 & 140 & $1: 99$ & 80 \\
\hline 3 & $\mathrm{PdCl}\left(\mathrm{C}_{3} \mathrm{H}_{5}\right)(\mathrm{dppb})(2)$ & $\mathrm{KOAc}$ & 3 & 140 & $0: 100$ & 81 \\
\hline 4 & $\mathrm{PdCl}\left(\mathrm{C}_{3} \mathrm{H}_{5}\right)(\mathrm{dppb})(1)$ & KOAc & 3 & 140 & $0: 100$ & 80 \\
\hline 5 & $\mathrm{PdCl}\left(\mathrm{C}_{3} \mathrm{H}_{5}\right)(\mathrm{dppb})(2)$ & KOAC & 2.2 & 140 & $1: 99$ & 78 \\
\hline 6 & $\mathrm{PdCl}\left(\mathrm{C}_{3} \mathrm{H}_{5}\right)(\mathrm{dppb})(2)$ & $\mathrm{KOAc}$ & 3 & 100 & $0: 100$ & 78 \\
\hline 7 & $\operatorname{PdCl}\left(\mathrm{C}_{3} \mathrm{H}_{5}\right)(\mathrm{dppb})(2)$ & $\mathrm{NaOAc}$ & 3 & 140 & $7: 93$ & 68 \\
\hline 8 & $\mathrm{PdCl}\left(\mathrm{C}_{3} \mathrm{H}_{5}\right)(\mathrm{dppb})(2)$ & $\mathrm{CsOAc}$ & 3 & 140 & $0: 100$ & 80 \\
\hline 9 & $\operatorname{PdCl}\left(\mathrm{C}_{3} \mathrm{H}_{5}\right)(\mathrm{dppb})(2)$ & $\mathrm{Cs}_{2} \mathrm{CO}_{3}$ & 3 & 140 & nd & $<5$ \\
\hline 10 & $\operatorname{PdCl}\left(\mathrm{C}_{3} \mathrm{H}_{5}\right)(\mathrm{dppb})(2)$ & $\mathrm{KOAc}$ & 3 & 140 & $72: 28$ & $52^{b}$ \\
\hline
\end{tabular}

${ }^{a}$ Conditions: 2,5-dibromothiophene (1 equiv), base (3 equiv), DMA, 20 h, isolated yields. ${ }^{\text {b}} 2,5$-Dibromothiophene (4 equiv), 2 -ethyl-4-methylthiazole (1 equiv), yield in $\mathbf{1 a}$.

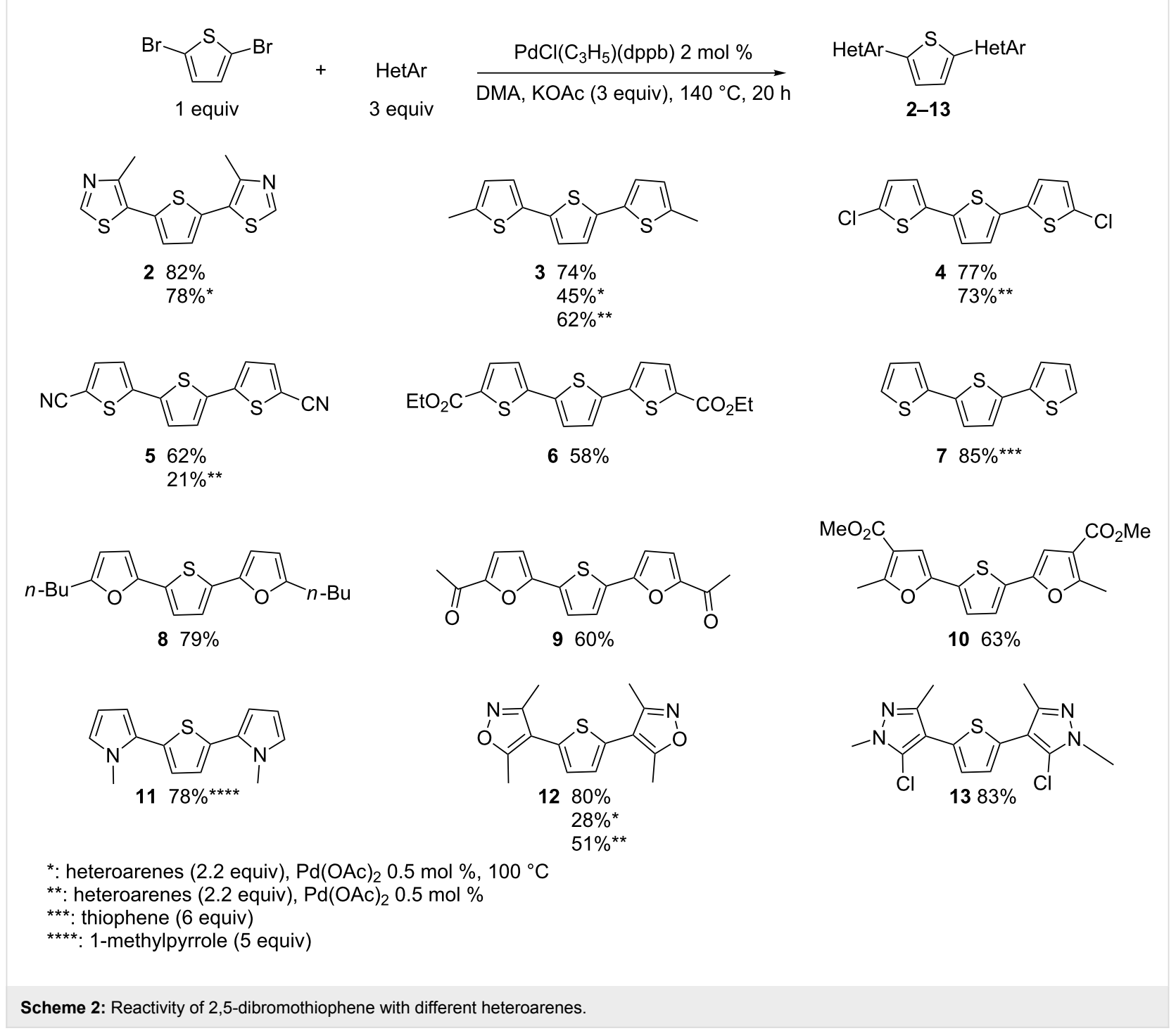


Both, 2-methyl- and 2-chlorothiophenes afforded the desired products 3 and 4 in good yields in the presence of $\mathrm{PdCl}\left(\mathrm{C}_{3} \mathrm{H}_{5}\right)(\mathrm{dppb})$ as the catalyst. Yields of $62 \%$ and $73 \%$ of these two products were obtained using $0.5 \mathrm{~mol} \% \mathrm{Pd}(\mathrm{OAc})_{2}$ catalyst at $140{ }^{\circ} \mathrm{C}$, whereas a reaction performed at $100{ }^{\circ} \mathrm{C}$ led to only a partial conversion of 2,5-dibromothiophene to afford $\mathbf{3}$ in $45 \%$ yield. This slightly lower reactivity of thiophene derivatives under these conditions was expected, as they are known to be less reactive than thiazole derivatives [44]. Moderate yields for 5 and $\mathbf{6}$ were obtained starting form thiophene-2-carbonitrile and ethyl thiophene-2-carboxylate, respectively in the presence of $2 \mathrm{~mol} \% \mathrm{PdCl}\left(\mathrm{C}_{3} \mathrm{H}_{5}\right)(\mathrm{dppb})$ catalyst due to the formation of unidentified degradation products. The use of 6 equiv of thiophene allowed the formation of 2,2':5',2"-terthiophene (7) in $85 \%$ yield. The reactivity of three furan derivatives was also studied using $\mathrm{PdCl}\left(\mathrm{C}_{3} \mathrm{H}_{5}\right)(\mathrm{dppb})$ as the catalyst. From 2-nbutylfuran, 8 was obtained in $79 \%$ yield, whereas 2 -acetylfuran and methyl 2-methylfuran-3-carboxylate afforded $\mathbf{9}$ and $\mathbf{1 0}$ in $60 \%$ and $63 \%$ yield, respectively. The reaction of 1 equiv of 2,5-dibromothiophene with 5 equiv of 1-methylpyrrole gave $\mathbf{1 1}$ in $78 \%$ yield. No significant formation of other polyheterocycles was observed by GC-MS analysis of the crude mixture.
Arylation at $\mathrm{C} 4$ of 3,5-dimethylisoxazole and 5-chloro-1,3dimethylpyrazole afforded $\mathbf{1 2}$ and $\mathbf{1 3}$ in $80 \%$ and $83 \%$ yields, respectively. With 3,5-dimethylisoxazole, a reaction performed using only $0.5 \mathrm{~mol} \% \mathrm{Pd}(\mathrm{OAc})_{2}$ catalyst at $100{ }^{\circ} \mathrm{C}$ led to a partial conversion of 2,5-dibromothiophene.

As several terthiophene derivatives bearing alkyl substituents at C3 in their central unit have been employed in material chemistry [2], the reactivity of 2,5-dibromo-3-methylthiophene was also examined (Scheme 3). Similar results to those of 2,5-dibromothiophene were obtained. Both, 2-ethyl-4-methylthiazole and 4-methylthiazole reacted nicely to afford $\mathbf{1 4}$ and $\mathbf{1 5}$ in $83 \%$ and 80\% yields, respectively. The four terthiophenes $\mathbf{1 6}-\mathbf{1 9}$ were also obtained in satisfactory yields. Again a moderate yield in 20 was obtained in the presence of methyl 2-methylfuran-3carboxylate due to the formation of degradation products, whereas the reaction with 1-methylpyrrole and 3,5dimethylisoxazole resulted in good yields of $\mathbf{2 1}$ and $\mathbf{2 2}$, respectively.

To our knowledge, the sequential Pd-catalyzed direct diheteroarylation of 2,5-dibromothiophene has not yet been reported. A<smiles>Cc1cc(Br)sc1Br</smiles>

1 equiv<smiles>CCc1nc(C)c(-c2cc(C)c(-c3sc(CC)nc3C)s2)s1</smiles>

$1483 \%$ $74 \% *$<smiles>Cc1cc(-c2ccc(Cl)s2)sc1-c1ccc(Cl)s1</smiles>

$1774 \%$<smiles>CC(=O)c1cc(-c2cc(C)c(-c3cc(C(C)=O)c(C)o3)s2)oc1C</smiles>

$2051 \%$
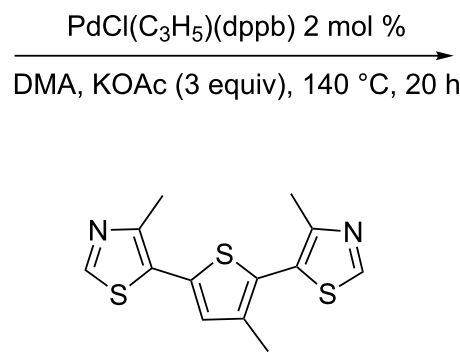

$1580 \%$<smiles>CCOC(=O)c1ccc(-c2cc(C)c(-c3ccc(C(=O)OCC)s3)s2)s1</smiles>

$1860 \%$

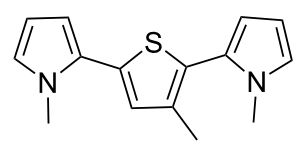

$2177 \%$ ***<smiles>Cc1cc([Ge])sc1C(Br)(Br)Br</smiles><smiles>Cc1ccc(-c2cc(C)c(-c3ccc(C)s3)s2)s1</smiles>

$1673 \%$ $33 \%$ *<smiles>Cc1cc(-c2cccs2)sc1-c1cccs1</smiles>

$1978 \%$ **<smiles>Cc1cc(-c2c(C)noc2C)sc1-c1c(C)noc1C</smiles>

$2275 \%$

*: heteroarenes (2.2 equiv), $\mathrm{Pd}(\mathrm{OAc})_{2} 0.5 \mathrm{~mol} \%, 100{ }^{\circ} \mathrm{C}$

**: thiophene ( 6 equiv)

***: 1 -methylpyrrole (5 equiv) 
sequential heteroarylation would allow the synthesis of nonsymmetrically 2,5-disubstituted thiophene derivatives. Our attempts to prepare these compounds are shown in Scheme 4. Eight heteroarenes were reacted with 1a to afford the 2,5-diheteroarylated thiophenes $\mathbf{2 3 - 3 0}$ in $41-89 \%$ yield. A high yield of $89 \%$ for $\mathbf{2 3}$ was obtained from $\mathbf{1 a}$ and 2-isobutylthiazole as the coupling partners. The reactions with 2-methylthiophene and thiophene-2-carbonitrile also afforded the desired products $\mathbf{2 4}$ and $\mathbf{2 5}$ in good yields. A decreased yield of $41 \%$ for $\mathbf{2 6}$ was obtained with thiophene as coupling partner, whereas, 1-methylpyrrole gave $\mathbf{2 7}$ in $74 \%$. Coupling of $\mathbf{1 a}$ with methyl 2-methylfuran-3-carboxylate afforded $\mathbf{2 8}$ in $62 \%$ yield. The arylation at $\mathrm{C} 4$ of 3,5-dimethylisoxazole and 5-chloro-1,3dimethylpyrazole also proceeded nicely to give $\mathbf{2 9}$ and $\mathbf{3 0}$ in $66 \%$ and $72 \%$ yield, respectively.

It should be noted that, for the synthesis of $\mathbf{2 4}$, the introduction of the thiazole unit in the first step (Scheme 1 and Scheme 4, $36 \%$ over 2 steps) led to a slightly higher yield than the introduction of 2-methylthiophene followed by the coupling with 2-ethyl-4-methylthiazole (Scheme 5, 32\% yield over 2 steps).

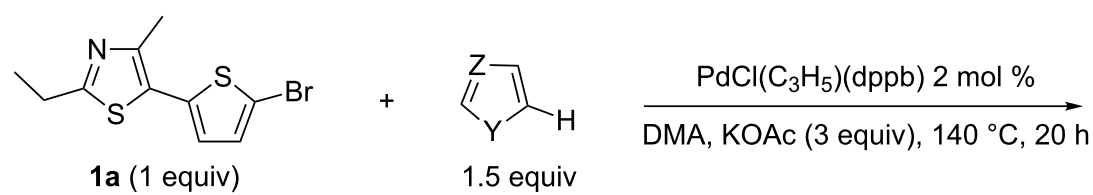<smiles>CCc1nc(C)c(-c2ccc(-c3cnc(CC(C)C)s3)s2)s1</smiles>

$2389 \%$<smiles>CCc1nc(C)c(-c2ccc(-c3cccs3)s2)s1</smiles>

$2641 \%$ *<smiles>CCc1nc(C)c(-c2ccc(-c3c(C)noc3C)s2)s1</smiles>

$2966 \%$

*: thiophene or 1 -methylpyrrole: 2 equiv<smiles>CCc1nc(C)c(-c2ccc(-c3ccc(C)s3)s2)s1</smiles>

$2470 \%$<smiles>[H][Y9]1cc(-c2cccn2C)sc1-c1sc(CC)nc1C</smiles>

$2774 \% *$<smiles>CCc1nc(C)c(-c2ccc(-c3c(C)nn(C)c3Cl)s2)s1</smiles>

$3072 \%$<smiles>[Y]c1[Y]c(-c2ccc(-c3sc(CC)nc3C)s2)cc1</smiles>

23-30

Scheme 4: Sequential diheteroarylation of 2,5-dibromothiophene.

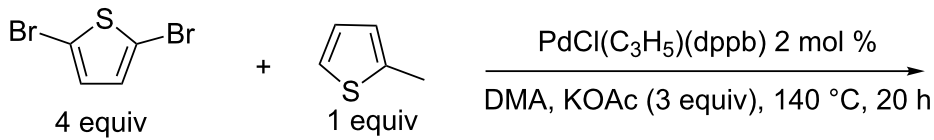<smiles>Cc1ccc(-c2ccc(-c3ccc(C)s3)s2)s1</smiles>

ratio $31: 392: 8$

$3135 \%$<smiles>Cc1ccc(-c2ccc(Br)s2)s1</smiles>

1 equiv

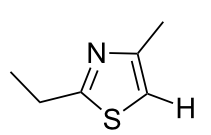

2 equiv
$\mathrm{PdCl}\left(\mathrm{C}_{3} \mathrm{H}_{5}\right)(\mathrm{dppb}) 2 \mathrm{~mol} \%$

$\overrightarrow{D M A}, \mathrm{KOAc}\left(3\right.$ equiv), $140{ }^{\circ} \mathrm{C}, 20 \mathrm{~h}$<smiles>CCc1nc(C)c(-c2ccc(-c3ccc(C)s3)s2)s1</smiles>

$2490 \%$ 
We also compared the preparation of 2,2':5',2"-terthiophene (7) starting from either 2,5-dibromothiophene (Scheme 2) or from 2 -bromothiophene (Scheme 6). The reaction of 1 equiv thiophene with 2 equiv of 2-bromothiophene resulted in a poor yield for 7 due to the formation of a mixture of bithiophene $\mathbf{3 2}$, terthiophene 7 and also a quaterthiophene (as was observed by GC-MS analysis of the crude mixture). On the other hand, the use of 6 equiv of thiophene in the presence of 1 equiv of 2-bromothiophene afforded $\mathbf{7}$ and $\mathbf{3 2}$ in a 30:70 ratio and only low amounts of a quaterthiophene were observed; compound 32 was isolated in $58 \%$ yield (Scheme 6, middle). The same reaction conditions allowed to prepare 1-methyl-2-(thiophen-2-yl)pyrrole (33) in $61 \%$ yield (Scheme 6, bottom).

Finally, as 4,7-diarylbenzothiadiazoles also display important physical properties [45], we applied our procedure to 4,7-dibromobenzothiadiazole which is commercially available (Scheme 7). In all cases, the desired 4,7-diarylbenzothiadiazoles 34-38 were obtained in high yields.

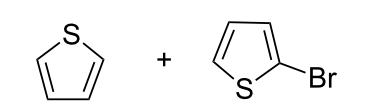

1 equiv<smiles>Brc1cccs1</smiles>

6 equiv 1 equiv<smiles>Cn1cccc1</smiles>

6 equiv

1 equiv

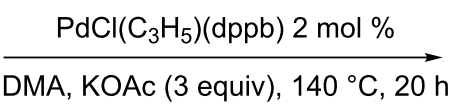

$\frac{\mathrm{PdCl}\left(\mathrm{C}_{3} \mathrm{H}_{5}\right)(\mathrm{dppb}) 2 \mathrm{~mol} \%}{\text { DMA, KOAc (3 equiv), } 140^{\circ} \mathrm{C}, 20 \mathrm{~h}}$

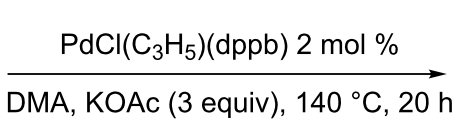

DMA, KOAc (3 equiv), $140^{\circ} \mathrm{C}, 20 \mathrm{~h}$<smiles>c1csc(-c2cccs2)c1</smiles>

32<smiles>c1csc(-c2cccs2)c1</smiles>

$3258 \%$

ratio 7:32 $30: 70$<smiles>Cn1cccc1-c1cccs1</smiles>

$3361 \%$

Scheme 6: Heteroarylation of 2-bromothiophene.<smiles>CC(C)(C)Oc1c(Br)cc(Br)c2nsnc12</smiles><smiles>CCc1nc(C)c(-c2ccc(-c3sc(CC)nc3C)c3nsnc23)s1</smiles>

$3492 \%$<smiles>Cn1cccc1-c1ccc(-c2cccn2C)c2nsnc12</smiles>

$3778 \%$ **
$\frac{\mathrm{PdCl}\left(\mathrm{C}_{3} \mathrm{H}_{5}\right)(\mathrm{dppb}) 2 \mathrm{~mol} \%}{\mathrm{DMA}, \mathrm{KOAc}\left(3 \text { equiv), } 140{ }^{\circ} \mathrm{C}, 20 \mathrm{~h}\right.}$<smiles>Cc1ccc(-c2ccc(-c3ccc(C)s3)c3nsnc23)s1</smiles>

$3586 \%$<smiles>Cc1noc(C)c1-c1ccc(-c2c(C)noc2C)c2nsnc12</smiles>

38 85\%

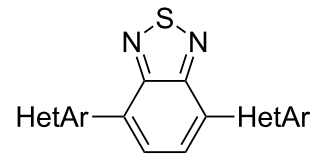

34-38<smiles>c1csc(-c2ccc(-c3cccs3)c3nsnc23)c1</smiles>

$3682 \%$ *

*: thiophene (6 equiv)

**: 1 -methylpyrrole ( 5 equiv) 


\section{Conclusion}

In summary we report here a simple one-pot catalytic method leading to 2,5-diheteroarylated thiophenes in good yields. We established that $2 \mathrm{~mol} \%$ of air-stable $\mathrm{PdCl}\left(\mathrm{C}_{3} \mathrm{H}_{5}\right)(\mathrm{dppb})$ catalyst (and in some cases $0.5 \mathrm{~mol} \% \mathrm{Pd}(\mathrm{OAc})_{2}$ catalyst) in the presence of KOAc as the base promotes the 2,5-diheteroarylation of 2,5-dibromothiophene in the presence of a variety of heteroarenes such as thiophenes, furans, pyrroles, pyrazoles or isoxazoles as the coupling partners. The sequential diheteroarylation of 2,5-dibromothiophene was also found to be possible to afford 2,5-diheteroarylated thiophenes bearing two different heteroarene units. As both, 2,5-dibromothiophene and a wide variety of heteroarenes are commercially available, this method gives a convenient access to a large number of terthiophene derivatives.

\section{Supporting Information}

\section{Supporting Information File 1}

Experimental procedures and characterization data. [http://www.beilstein-journals.org/bjoc/content/ supplementary/1860-5397-10-309-S1.pdf]

\section{Acknowledgements}

We thank the Centre National de la Recherche Scientifique, "Rennes Metropole" for providing financial support.

\section{References}

1. Liu, Y.; Ye, M.; Guo, H.-Z.; Zhao, Y.-Y.; Guo, D.-A.

J. Asian Nat. Prod. Res. 2002, 4, 175-178. doi:10.1080/1028602021000000071

2. Gohier, F.; Frère, P.; Roncali, J. J. Org. Chem. 2013, 78, 1497-1503. doi:10.1021/jo302571u

3. Li, J. J.; Gribble, G. W. Palladium in Heterocyclic Chemistry; Pergamon: Amsterdam, 2000.

4. Negishi, E., Ed. Handbook of Organopalladium Chemistry for Organic Synthesis; Part III; Wiley-Interscience: New York, 2002; p 213.

5. Schnürch, M.; Flasik, R.; Khan, A. F.; Spina, M.; Mihovilovic, M. D.; Stanetty, P. Eur. J. Org. Chem. 2006, 3283-3307. doi:10.1002/ejoc.200600089

6. Tung, D. T.; Tuân, D. T.; Rasool, N.; Villinger, A.; Reinke, H.; Fischer, C.; Langer, P. Adv. Synth. Catal. 2009, 351, 1595-1609. doi:10.1002/adsc.200900044

7. Pernites, R. B.; Ponnapati, R. R.; Advincula, R. C. Adv. Mater. 2011, 23, 3207-3213. doi:10.1002/adma.201100469

8. Zhou, J.; Xie, S.; Amond, E. F.; Becker, M. L. Macromolecules 2013, 46, 3391-3394. doi:10.1021/ma400531v

9. Qian, D.; Ma, W.; Li, Z.; Guo, X.; Zhang, S.; Ye, L.; Ade, H.; Tan, Z.; Hou, J. J. Am. Chem. Soc. 2013, 135, 8464-8467. doi:10.1021/ja402971d

10. Tanaka, S.; Tanaka, D.; Tatsuta, G.; Murakami, K.; Tamba, S.; Sugie, A.; Mori, A. Chem. - Eur. J. 2013, 19, 1658-1665. doi:10.1002/chem.201203331
11. Nagura, K.; Saito, S.; Yusa, H.; Yamawaki, H.; Fujihisa, H.; Sato, H.; Shimoikeda, Y.; Yamaguchi, S. J. Am. Chem. Soc. 2013, 135, 10322-10325. doi:10.1021/ja4055228

12. Klingstedt, T.; Shirani, H.; Åslund, K. O. A.; Cairns, N. J.; Sigurdson, C. J.; Goedert, M.; Nilsson, K. P. R. Chem. - Eur. J. 2013, 19, 10179-10192. doi:10.1002/chem.201301463

13. Mallet, C.; Didane, Y.; Watanabe, T.; Yoshimoto, N.; Allain, M.; Videlot-Ackermann, C.; Frère, P. ChemPlusChem 2013, 78, 459-466. doi:10.1002/cplu.201300037

14. Bruns, C. J.; Herman, D. J.; Minuzzo, J. B.; Lehrman, J. A.; Stupp, S. I. Chem. Mater. 2013, 25, 4330-4339. doi:10.1021/cm402505p

15. Salamoun, J.; Anderson, S.; Burnett, J. C.; Gussio, R.; Wipf, P. Org. Lett. 2014, 16, 2034-2037. doi:10.1021/ol500620m

16. Ferrer Flegeau, E.; Popkin, M. E.; Greaney, M. F. J. Org. Chem. 2008, 73, 3303-3306. doi:10.1021/jo800121y

See for access to trisoxazoles.

17. Ohta, A.; Akita, Y.; Ohkuwa, T.; Chiba, M.; Fukunaga, R.; Miyafuji, A.; Nakata, T.; Tani, N.; Aoyagi, Y. Heterocycles 1990, 31, 1951-1958. doi:10.3987/COM-90-5467

18. Aoyagi, Y.; Inoue, A.; Koizumi, I.; Hashimoto, R.; Tokunaga, K.; Gohma, K.; Komatsu, J.; Sekine, K.; Miyafuji, A.; Kunoh, J.; Honma, R.; Akita, Y.; Ohta, A. Heterocycles 1992, 33, 257-272. doi:10.3987/COM-91-S29

19. Alberico, D.; Scott, M. E.; Lautens, M. Chem. Rev. 2007, 107, 174-238. doi:10.1021/cr0509760

20. Satoh, T.; Miura, M. Chem. Lett. 2007, 36, 200-205. doi:10.1246/cl.2007.200

21. Li, B.-J.; Yang, S.-D.; Shi, Z.-J. Synlett 2008, 949-957. doi:10.1055/s-2008-1042907

22. Bellina, F.; Rossi, R. Tetrahedron 2009, 65, 10269-10310. doi:10.1016/j.tet.2009.10.015

23. Ackermann, L.; Vincente, R.; Kapdi, A. R. Angew. Chem., Int. Ed. 2009, 48, 9792-9826. doi:10.1002/anie.200902996

24. Roger, J.; Gottumukkala, A. L.; Doucet, H. ChemCatChem 2010, 2 , 20-40. doi:10.1002/cctc.200900074

25. Wu, X.-F.; Anbarasan, P.; Neumann, H.; Beller, M. Angew. Chem., Int. Ed. 2010, 49, 7316-7319. doi:10.1002/anie.201003895

26. Kuhl, N.; Hopkinson, M. N.; Wencel-Delord, J.; Glorius, F. Angew. Chem., Int. Ed. 2012, 51, 10236-10254. doi:10.1002/anie.201203269

27. Yamaguchi, J.; Yamaguchi, A. D.; Itami, K. Angew. Chem., Int. Ed. 2012, 51, 8960-9009. doi:10.1002/anie.201201666

28. Wencel-Delord, J.; Glorius, F. Nat. Chem. 2013, 5, 369-375. doi:10.1038/nchem.1607

29. Kuzhushkov, S. I.; Potukuchi, H. K.; Ackermann, L. Catal. Sci. Technol. 2013, 3, 562-571. doi:10.1039/c2cy20505j

30. Yuan, K.; Doucet, H. Chem CatChem 2013, 5, 3495-3496. doi:10.1002/cctc.201300533

31. Rossi, R.; Bellina, F.; Lessi, M.; Manzini, C. Adv. Synth. Catal. 2014, 356, 17-117. doi:10.1002/adsc.201300922

32. He, M.; Soulé, J.-F.; Doucet, H. ChemCatChem 2014, 6, 1824-1859. doi:10.1002/cctc. 201402020

33. Beydoun, K.; Zaarour, M.; Williams, J. A. G.; Doucet, H.; Guerchais, V. Chem. Commun. 2012, 48, 1260-1262. doi:10.1039/c2cc16327f

34. Zhao, L.; Bruneau, C.; Doucet, H. Chem. Commun. 2013, 49, 5598-5600. doi:10.1039/c3cc42226g

35. Xu, Y.; Zhao, L.; Li, Y.; Doucet, H. Adv. Synth. Catal. 2013, 355 , 1423-1432. doi:10.1002/adsc.201300123 
36. Yuan, K.; Doucet, H. Chem. Sci. 2014, 5, 392-396. doi:10.1039/c3sc52420e

37. Borghese, A.; Geldhof, G.; Antoine, L. Tetrahedron Lett. 2006, 47, 9249-9252. doi:10.1016/j.tetlet.2006.10.130

38. Shibahara, F.; Yamaguchi, E.; Murai, T. Chem. Commun. 2010, 46, 2471-2473. doi:10.1039/b920794e

39. Kowada, T.; Ohe, K. Bull. Korean Chem. Soc. 2010, 31, 577-581. doi:10.5012/bkcs.2010.31.03.577

40. Murata, T.; Murai, M.; Ikeda, Y.; Miki, K.; Ohe, K. Org. Lett. 2012, 14, 2296-2299. doi:10.1021/ol300718x

41. Koszarna, B.; Matczak, R.; Krzeszewski, M.; Vakuliuk, O.; Klajn, J.; Tasior, M.; Nowicki, J. T.; Gryko, D. T. Tetrahedron 2014, 70, 225-231. doi:10.1016/j.tet.2013.11.088

42. Fu, H. Y.; Chen, L.; Doucet, H. J. Org. Chem. 2012, 77, 4473-4478. doi:10.1021/jo300528b

43. Zhao, L.; Bruneau, C.; Doucet, H. ChemCatChem 2013, 5, 255-262. doi: $10.1002 /$ cctc. 201200521

44. Bensaid, S.; Doucet, H. Chem SusChem 2012, 5, 1559-1567. doi:10.1002/cssc.201100771

45. Cai, T.; Zhou, Y.; Wang, E.; Hellström, S.; Zhang, F.; Xu, S.; Inganäs, O.; Andersson, M. R. Sol. Energy Mater. Sol. Cells 2010, 94, 1275-1281. doi:10.1016/j.solmat.2010.03.024

\section{License and Terms}

This is an Open Access article under the terms of the Creative Commons Attribution License

(http://creativecommons.org/licenses/by/2.0), which permits unrestricted use, distribution, and reproduction in any medium, provided the original work is properly cited.

The license is subject to the Beilstein Journal of Organic Chemistry terms and conditions:

(http://www.beilstein-journals.org/bjoc)

The definitive version of this article is the electronic one which can be found at:

doi:10.3762/bjoc. 10.309 